\title{
Apropriasi Musikal dan Estetika Musik Gamat
}

\author{
Martarosa $^{1}$ \\ Institut Seni Indonesia Padang Panjang
}

\author{
GR. Lono L. Simatupang, Timbul Haryono, dan Victor Ganap
}

Pengkajian Seni Pertunjukan dan Seni Rupa, Universitas Gadjah Mada Yogyakarta

\begin{abstract}
ABSTRAK
Penelitian ini membahas cara orang Pesisir Minangkabau mengimbuhkan atau mencangkokkan beberapa genre musik tradisional Pesisir Minangkabau hingga genre musik ini menjadi semakin kuat diakui sebagai musik mereka. Penelitian difokuskan pada perubahan dan estetika. Secara musikologis data dipisahkan menjadi dua aspek yaitu aspek musikal dan aspek sosial atau tekstual dan kontekstual. Secara tekstual data dianalisis berdasarkan konsep estetika yang meliputi harmoni dan orkestrasi yang menyangkut penyajian formasi instrumen. Konsep ini dapat digunakan untuk melihat bentukbentuk apropriasi musikal yang terjadi pada musik gamat sebagai kajian analisis dalam bentuk dan struktur, vibrato dan ornamentasi melalui teknik penyajian garitiak dan gayo. Berdasarkan penelitian dapat disimpulkan bahwa proses interaksi dan cara kepemilikan atau apropriasi terhadap musik gamat oleh orang-orang Minangkabau diduga terjadi melalui penawaran-penawaran pada sisi musikal antar budaya timbal balik.
\end{abstract}

Kata kunci: gamat; apropriasi; musik Minangkabau

\begin{abstract}
The Musical Appropriation and the Aesthetics of Gamat Music. This study discusses the way of Coastal people of Minangkabau add or graft some genres of traditional music of Costal of Minangkabau to the genre of this music which becomes strongly recognized as their own music. Research is focused on the change and its aesthetics. The musical data is separated into two aspects: musical aspects and social or textual and contextual aspects. Textually the data is analyzed based on the aesthetic concepts which include harmony and orchestration concerning the presentation of instrument formation. This concept can be used to look at musical forms of appropriation that occur in gamat music as a study of analysis towards its form and structure, vibrato and ornamentation through the technique of preparing garitiak and gayo. Based on the research, it can be concluded that the process of interaction and the way of ownership or appropriation of musical gamat by Minangkabau people allegedly occurred through offerings on the intercultural musical reciprocity.
\end{abstract}

Keywords: gamat; appropriation; Minangkabau Music

\section{Pendahuluan}

Musik merupakan bahasa universal di samping memiliki nilai-nilai estetika lokal, musik juga memiliki nilai-nilai estetika universal yang dapat diterima oleh seluruh kalangan masyarakat di dunia tanpa batasan suku, ras, warna kulit dan geografis. Tumbuh dan berkembangnya musik-musik daerah dapat menjadi simbol serta identitas bagi masyarakat suatu daerah untuk menunjukkan eksistensinya. Tumbuh dan berkembangnya seni budaya dari berbagai daerah di Nusantara merupakan sebuah identitas yang dapat menggambarkan sebuah dinding, dimana

Alamat korespondensi: Jurusan Musik, Fakultas Seni Pertunjukan ISI Padang Panjang. Jln. Bundokanduang 35, Padang Panjang - 27128. E-mail: marta23365rossa@gmail.com. HP: 08126729103 
kedua ujungnya bertemu, sungguhpun terjadi pemisahan antara ruang dalam dipandang dari ruang luar (Simatupang, 2013: 239).

Secara umum, di samping terkait dengan tumbuh dan berkembangnya musik-musik di Nusantara, tidak dapat pula dipisahkan dari perjalanan sejarah akibat kolonialisme di Indonesia. Dampak kolonialisme tidak hanya terasa di wilayah Barat Indonesia tetapi juga marak di wilayah Timur Indonesia. Mulai dari zaman Portugis sampai zaman Jepang banyak mempengaruhi perkembangan musik di Nusantara. Hal ini terjadi dimulai sejak abad ke-16 yang merupakan awal dari diseminasi musik Barat di Indonesia yang pertamatama terjadi di kepulauan Maluku melalui kegiatan para pedagang dan misionaris Portugis. Secara elementer musik-musik Portugis berkembang pada musik-musik rakyat Jangere di Tobello, Halmahera Utara. Tidak berlebihan dapat dikatakan bahwa perkembangan musik tersebut, merupakan salah satu penanda bahwa Portugis pernah masuk ke Indonesia (Bramantyo, 2004: 62-86).

Dari berbagai proses penyebaran dan interaksi yang cukup panjang, kehadiraan musik di Indonesia dapat berfungsi ganda dengan masuknya pengaruh musik Barat ke Indonesia melalui tiga jalur meliputi: institusi keagamaan, lembaga pendidikan dan media radio (Ganap, 2011: 127-128). Ini merupakan hal sangat ampuh untuk penyebaran musik dari wilayah yang satu ke wilayah lainnya atau dari institusi yang satu ke institusi lainnya kepada masyarakat di Nusantara.

Uraian di atas menandakan bahwa pengaruh bangsa Eropa dalam perkembangan musik Indonesia terutama dalam perkembangan musikmusik daerah sangat besar dan menyebabkan beragamnya jenis-jenis musik di Indonesia meliputi: musik keroncong di Jawa, musik gambang kromong di Banten, musik gazal di Riau, musik ronggeng di Sumatera Utara, dan musik gamat di Pesisir Sumatera Barat Minangkabau. Tumbuh dan berkembangnya musik-musik tersebut saling mempengaruhi dan berinteraksi antara musik yang satu dengan musik-musik yang lainnya. Hal ini dapat diperhatikan dengan mendengarkan nada, sya'ir, dan irama yang dimainkan oleh masingmasing jenis musik-musik tersebut, sebagai ciri dan gaya dalam bentuk elemen-elemen musik yang disajikannya.

Begitu juga dengan musik gamat. Musik ini merupakan salah satu bentuk genre seni pertunjukan musik Melayu yang tumbuh dan berkembang sebagai seni budaya masyarakat di Pesisir Minangkabau Sumatera Barat. Musik gamat di samping mengunakan syair dan pantun juga menggunakan gabungan musik instrumental dengan musik vokal. Gamat biasanya diikuti dengan tari-tarian spontan, baik dalam bentuk joget maupun langgam yang dilakukan oleh para vokalis maupun penonton secara bebas, relatif cenderung dilakukan dengan gerak monoton (Gambar 1).

\section{Konsep Apropriasi Musikal dan Estetika Musik Gamat}

Proses apropriasi musik gamat terjadi dalam bentuk multi kultural secara komplek dalam perwujudan budaya masyarakat Pesisir Minangkabau Sumatera Barat, sebagai salah satu pewaris budaya dari penjajahan kolonial. Hal ini juga ditegaskan oleh Sumarsam (2016: 99) bahwa sejarah Indonesia mencakup suatu suksesi interaksi dengan budaya-budaya asing meliputi: budaya Hindu, Islam, dan Barat yang membawa dampak penting atas perkembangan budaya Indonesia. Sebagaimana interaksi-interaksi tersebut cukup banyak mempengaruhi pertumbuhan tradisi kultural Indonesia, dalam pelokalan dan penghibridan unsur-unsur asing.

Oleh karenanya kajian ini mengacu pada konsep-konsep poskolonial dalam bentuk multi disiplin di bawah payung disiplin 'musik studies' yang meliputi kajian musikologis dan

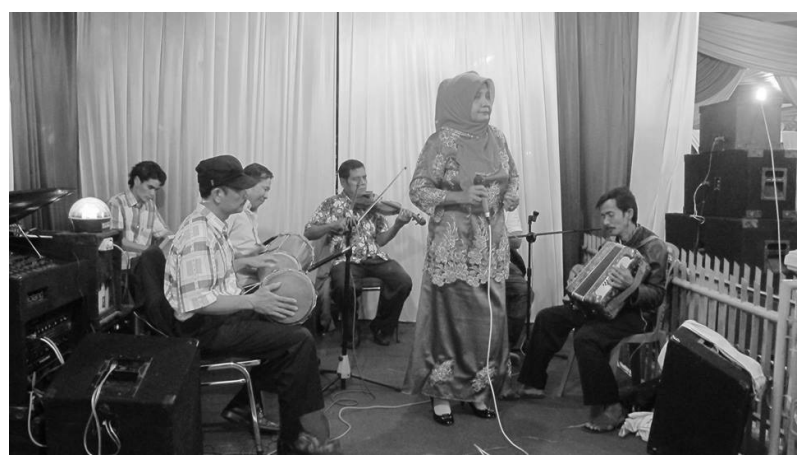

Gambar 1. Pertunjukan musik Gamat kota Padang grup "Gurindam Lamo" (Foto: Martarosa) 
etnomusiklogis. Disiplin musik studies mampu mengkaji hal-hal yang tidak terjamah atau termarjinalkan dalam bentuk musikal secara analitik yang selama ini membungkam di luar disipilin kajian musikologis dan etnomusikologis. Kajian musikologis dimaksudkan untuk memahami musik gamat dalam konsep apropriasi musikal baik yang dipengaruhi dari luar maupun dari dalam yang dilakukan oleh orang-orang Pesisir Minangkabau. Untuk itu perlu kajian konteks yang mendukungnya yaitu konsep apropriasi musikal yang terjadi pada masa lampau yang tumbuh berkembang sampai sekarang ini.

Proses interaksi yang terjadi dalam bentukbentuk unsur musikal sebagai kepemilikan atau apropriasi terhadap musik ini oleh orang-orang Pesisir Minangkabau diduga terjadi melalui penawaran-penawaran pada sisi musikal antar budaya timbal balik. Makna musikal yang dimaksud meliputi unsur-unsur bunyi, nada, ritme, melodi, harmoni, tonalitas, bentuk, ekspresi, pertunjukan, hingga menjadi sebuah kebudayaan (Irawan, 2014, 20). Apropriasi merupakan sebuah konsep penciptan bentuk baru, dalam artian pengambilan sebuah elemen dalam bentuk aspek atau teknik yang digunakan dalam proses pembuatan sepotong penciptaan baru, dan dapat diterima sebagian pengakuan budaya (http://en.wikipedia.org/ wiki/ Appropriation).

Schneider (2006: 19-20) secara kritis juga membahas tentang konsep apropriasi dan mengevaluasi kegunaan, menerapkan perampasan istilah dalam analisis komunikasi lintas budaya di dunia global. Menurut Schneider 'apropriasi' adalah sebuah kesesuaian dalam penciptaan sebuah karya seni rupa kontemporer yang melibatkan perampasan meliputi: ide, simbol, dan artefak dari budaya lain.

Menurut J.P.E. Harper-Scott dan Jim Samson (2009: 58) kegiatan apropriasi adalah mengklaim atau mengambil ide-ide dari berbagai elemenelemen musik atau gaya kepemilikan seseorang dengan mencoba merubah kerangka yang terkait pada suatu acuan. Ketiga pengertian apropriasi di atas dapat dikembangkan dan diacu sebagai landasan dasar untuk melihat fenomena yang terjadi pada perkembangan musik di Nusantara khususnya musik gamat sebagai budaya masyarakat di Pesisir Minangkabau. Oleh karena itu secara konseptual dapat disimpulkan bahwa apropriasi adalah sebuah perampasan atau pengambilan bentuk kesesuaian karya seni (kreatifitas) meliputi: ide-ide, elemenelemen musik, simbol, dan artefak dari kepemilikan berbagai budaya lain, kemudian mencoba merubah kerangka yang terkait pada suatu acuan, sehingga dapat dijadikan sebagai miliknya sendiri.

Estetika musik gamat sebagai budaya masyarakat Minangkabau di Pesisir Sumatera Barat dihadirkan/dipertahankan dalam masing-masing varian musik gamat sebagai genre dari musik Melayu Serumpun akan mengacu pada konsep seperti diungkapkan Kaemer (1993: 214):

\begin{abstract}
Although the Western aesthetic has long been concerned with concepts of beauty, it has more recently developed into a treatment of the overall value given to the "fine arts." Thus, the term "aesthetics" today often refers to the general value given to music legitimated by the elite, including symbolic or pragmatic values not necessarily associated with aspects of beauty.
\end{abstract}

(Meskipun estetika Barat telah lama konsen terhadap konsep keindahan, baru-baru ini juga telah berkembang menjadi suatu perlakuan seluruh nilai terhadap "seni rupa." Dengan demikian, istilah "estetika" sekarang mengacu pada nilai umum yang diberikan terhadap musik, termasuk nilai-nilai simbolik atau nilainilai pragmatis yang tidak selalu terkait dengan aspek-aspek keindahan.)

Sementara itu, kualitas intrinsik dalam kasus musik, "... include features such as tone quality, rhythmic patterns, or melodies that appreciated for their own sake." ( d'Azevedo dalam Kaemer, 1993: 215) termasuk fitur seperti kualitas nada, pola ritmik, atau melodi yang dihargai untuk kepentingan unsur-unsur musikal itu sendiri. Lebih lanjut juga ditegaskan oleh Simatupang (2006) bahwa nilai-nilai rasa (estetis) tersebut diberikan, dilekatkan, dan dibiasakan oleh masyarakat sebagai semacam pedoman interaksi bagi pribadi-pribadi warga masyarakat. Dalam artian nilai-nilai rasa (estetika) merupakan hasil interaksi antara manusia dengan gejala-gejala (estetis) yang dialaminya, keduanya terkait secara dialogis dan dialektis. 
Estetika music gamat juga pernah diteliti oleh Murniati (2015). Dalam penelitiannya disimpulkan bahwa dekonstruksi music gamat merupakan pergeseran bentuk yang Nampak dari struktur organisasi masyarakat pelaku seni yang heterogen, aspek bentuk dan struktur sajian, estitika, serta konteks waktu pertunjukan. Estetika keberagaman musik gamat terwujud dari rasa saling menerima antarbudaya yang berbeda dalam pertunjukan. Dekonstruksi estetika mengandung makna pembauran, kreativitas, dan ekspresi serta estetika multikultural.

Maruska Svasek (2007:9) telah melangkah lebih jauh dengan memberi perhatian terutama pada proses pembentukan atau konstruksi nilai estetik. Dia menyarankan untuk lebih memperhatikan estetikanisasi (aestheticisation). Svasek menggunakan istilah estetikisasi untuk mengkonseptualisasikan, dimana sebuah proses seseorang dalam menafsirkan pengalaman sensorik tertentu merupakan bagian yang berharga. Terlepas dari pengertian tentang 'seni' dan 'estetika', Svasek menyatakan bahwa proses aestheticisation berlangsung dalam dan di luar bidang praktek artistik itu sendiri.

Menggunakan persepktif tersebut, Svasek menjangkau pembahasan tentang pemberian nilai-nilai pada obyek dan gejala inderawi dengan mengajukan dua konsep utama, yakni transit dan transition. Yang dimaksud dengan transit adalah perpindahan obyek materi kultural tertentu dari suatu tempat/konteks budaya ke tempat/konteks budaya yang lain. Sementara itu, seiring dengan perpindahan tersebut terjadi pula pergeseran atau perubahan nilai yang dilekatkan orang pada obyek tersebut. Proses yang terakhir inilah yang ia sebut dengan transition. Melalui kedua konsep tersebut Svasek membicarakan dinamika estetikisasi yang berlangsung tatkala obyek-obyek ritual diberi nilai estetik, obyek sehari-hari dijadikan karya seni, termasuk di dalamnya perihal penyematan nilai ekonomis kepada gejala seni (komoditisasi) (Svasek, 2007: 4-5). Hal ini serupa dengan musik gamat yang mengalami perpindahan dari tempat asalnya ke berbagai tempat/konteks budaya yang berbeda-beda. Lebih lanjut Svasek menyatakan bahwa perpindahan artefak budaya tersebut selalu mengakibatkan berlangsungnya perubahan dan pergeseran nilai atas artefak budaya yang berpindah tersebut. Perubahan nilai itulah yang oleh Svasek (2007: 11) diberi label transition. Pendapat Svasek tentang transition ini bermanfaat untuk menganalisis kontinuitas perubahan-perubahan dan perbedaan-perbedaan nilai serta perlakuan yang dikenakan pada musik gamat baik di kalangan orang Pesisir Minangkabau itu sendiri maupun sebagai budaya yang datang dari luar secara timbal balik.

Penelitian ini memfokuskan pada cara orangorang Pesisir Minangkabau mengimbuhkan atau mencangkokan genre musikal musik tradisi Pesisir Minangkabau hingga genre musik ini menjadi semakin kuat diakui sebagai musik milik mereka. Secara elementer unsur-unsur musikal yang tumbuh dan berkembang dalam penyajian musik gamat di samping dipengaruhi dari budaya luar dan musik Melayu Srumpun, juga dipengaruhi oleh budaya dari dalam secara timbal balik, bersumber dari estetika genre musik tradisi Pesisir Minangkabau itu sendiri.

Unsur-unsur musikal ini terlihat dari olahan atau jalinan dalam penggarapan konsep kreativitas melodi, musik vokal dan instrumental yang digarap dalam bentuk garitiak untuk musik instrumen dan gayo untuk musik vokal. Garitiak merupakan kepiawaian para instrumentalis dalam menyajikan sebuah teknik permainan instrumen musik berdasarkan style musik tradisi Minangkabau melalui kreativitas pengolahan nada-nada dalam bentuk nada hias (ornamentasi). Gayo merupakan kepiawaian para vokalis dalam menyajikan sebuah teknik vokal musik gamat berdasarkan style musik tradisi minangkabau melalui kreativitas pengolahan nada-nada dalam bentuk nada hias (ornamentasi) dan vibrato.

Secara estetika musikal istilah garitiak dalam bentuk permainan instrumen musik di daerah darek (Luhak Nan Tigo) Minangkabau juga lazim disebutkan di dalam permainan musik tradisi seperti: rabab, dendang pauah, saluang dan talempong. Begitu juga didalam permainan musik vokal atau dendang disebut garinyiak. Garinyiak adalah sebuah isian variassi dalam bentuk melodi yang disajikan melalui vokal atau pedendang. Secara umum istilah garinyiak juga dipakai dalam 
penggarapan musik instrumen oleh para pemusik tradisi di daerah darek Minangkabau (Sriyanto, 2012: 227). Setiap individu memiliki kemampuan impropisasi yang berbeda-beda baik sebagai pemain musik tradisi maupun sebagai vokalis atau pedendang atau sebagai tukang kaba dalam musik tradisi rabab.

Hendrizal (2013: 45-46) mengungkapakan bahwa garinyiak adalah sebuah teknik bermain biola pada musik gamat, mirip seperti triller pada musik konvensional Barat. Bedanya, pada musik barat dengan menggerakan jarak nada seconde ke atas, sedangkan pada musik gamat, triller digerakan dengan jarak nada seconde ke bawah. Diungkapkan juga bentuk garinyiak yang lain yang terdapat pada musik gamat meliputi: mordent (melodi yang melangkah jarak nada seconde), appogiatura, dan appogiatura ganda. Sedangkan untuk vokal dinamakannya cengkok dengan menggunakan triol (tiga nada), septol (enam nada), dan septimol (tujuah nada). Kedua sebutan teknik permainan musik seperti garinyiak dan cengkok tidak lazim digunakan oleh para pemain musik gamat di daerah Pesisir Minangkabau. Garitiak berlaku untuk semua permainan instrumen musik melodis yang disajikan dalam musik gamat seperti: biola, akordeon, alto saxophone dan gitar. Untuk musik vokal mereka sebut gayo (Tawanto Karim, 2015).

Menurut Perry Romengan (2010: 1-3), untuk mengetahui terjadinya sebuah perbedaan musik yang satu dengan musik yang lain dapat terlihat pada atmosfir musik itu sendiri. Perwujudan tersebut terlihat berupa ide-ide musikal dari berbagai macam bentuk meliputi: (1) ide programatik yaitu ide yang datang dari luar bunyi, biasanya ditemui pada musik vokal dan banyak dipengaruhi oleh unsur-unsur sasteranya; (2) ide absolut yaitu satu ide yang keluar dari hasil interaksi bunyi musikal semata, biasanya muncul setelah mendengar hasil interaksi bunyi sebelumnya. Apapun bentuk ide musikal yang melatarbekanginnya oleh penikmat musik secara langsung tidak lain adalah atmosfir bunyi. Atmosfir bunyi ini ditentukan oleh dua hal yaitu yang bersifat abstrak (ide) dan yang bersifat fisik (elemen-elemen).

Keberadaan bunyi musik juga dipengaruhi oleh sistem gramatika, cara, materi yang digunakan, sumber daya yang merancang, dan mengekspresiskannya (komponis atau artis), termasuk di dalamnya temperamen, latar belakang, serta pengalaman bunyi dari kedua pihak tersebut (Perry Romengan, 2010: 3).

Jenis pola irama yang disajikan pada musik gamat ini adalah bercorak langgam dengan memakai tempo 4/4 dan joget dengan memakai tempo 2/4, 4/4, diasumsikan lebih mengutamakan teks lagu di samping bentuk-bentuk tari sebagai varian iringannya. Berbeda dengan joget musik Melayu Serumpun (Melayu Riau, Melayu Sumatera Utara dan Melayu Melaka) dengan memakai tempo 6/8 yang lebih mengutamakan musik sebagai iringan tari di samping juga teks lagu.

Ditilik secara musikal, musik Melayu di Pesisir Minangkabau banyak ditemui munculnya ekspresi musikal dalam bentuk wujud melisma, melalui bentuk-bentuk ornamnentasi dan vibrato. Melisma artinya adalah sekelompok nada atau banyak nada dinyanyikan dalam bentuk satu suku kata dari teks dan digunakan secara intensif dalam bernyanyi (Christine Ammer, 2004: 237). Mempelajari gaya bernyanyi seperti ini sama halnya dengan mempelajari teknik dan kebiasaan bernyanyi, dan bukan terletak pada materi nyanyian itu sendiri, melainkan harus dilihat pula dari perilaku menyanyikannya (teknik atau cara kerjanya) (Mistortoify, 2014: 2). Bentuk dan struktur musik seperti ini banyak ditemukan atau dijumpai pada musik Melayu dan musik gamat. Namun lain dengan musik gamat sebagai genre musik Melayu di Pesisir Minangkabau, di samping munculnya ekspresi musikal dalam bentuk wujud melisma, melalui bentuk-bentuk ornamenentasi dan vibrato secara musikal ekspresi yang diwujudkannya bersumber pula dari musik tradisi masyarakat Pesisir Minangkabau itu sendiri yaitu musik bakaba rabab pasisie dan dendang pauah.

\section{Analisis Lagu Musik Gamat “Ratok Dagang”}

Ditinjau dari analisis musikal sangat memungkinkan terlihat terjadinya apropriasi musikal yang mengakar dari musik-musik tradisi Pesisir Minangkabau dalam bentuk ornamentasi dan vibrato yang dimainkan melalui bentuk teknik 
penyajian garitiak dan gayo. Bentuk dan struktur musikal tersebut secara elementer bersumber dari musik-musik tradisi masyarakat Pesisir Minangkabau yang didominasi dalam bentuk gaya musik tradisi bakaba rabab pasisie dan dendang pauah. Proses tumbuh dan berkembangnya musik gamat sebagai budaya masyarakat di Pesisir Minangkabau Sumatera Barat, di samping terjadi apropriasi musikal dari musik-musik Portugis (Eropa) dan Melayu (Islam) juga dengan berbagai bentuk-bentuk musikal musik tradisi masyarakat Pesisir Minangkabau itu sendiri. Terlihat pada salah satu lagu gamat berjudul Ratok Dagang (Notasi 1).

\section{Bentuk dan Struktur Melodi Introduksi}

Bentuk dan struktur melodi introduksi lagu gamat berjudul Ratok Dagang merupakan satu bagian kecil dalam bentuk kalimat musik terdiri dari satu frase antecedent dan satu frase consequent dengan jumlah sembilan birama. Struktur melodi dimulai dari nada d sebagai tonika dalam tangganada mayor diakhiri dengan nada b sebagai nada ke enam. Adapun bentuk apropriasi musikal yang terjadi pada melodi introduduksi, proses pembentukannya dapat ditandai dengan adanya penggunaan sistem tangga nada diatonis Barat dan Arab, dipadukan dengan ornamentasi musik tradisi Pesisir Minangkabau menyerupai melodi musik pembuka pertunjukan Rabab Pasisie dalam bentuk garitiak. Hal ini dapat terlihat pada lagu gamat berjudul Ratok Dagang pada notasi melodi introduksi sebagai berikut.

(a) Terlihat pada penandaan tanda kunci G pada notasi di atas, dimulai dari birama

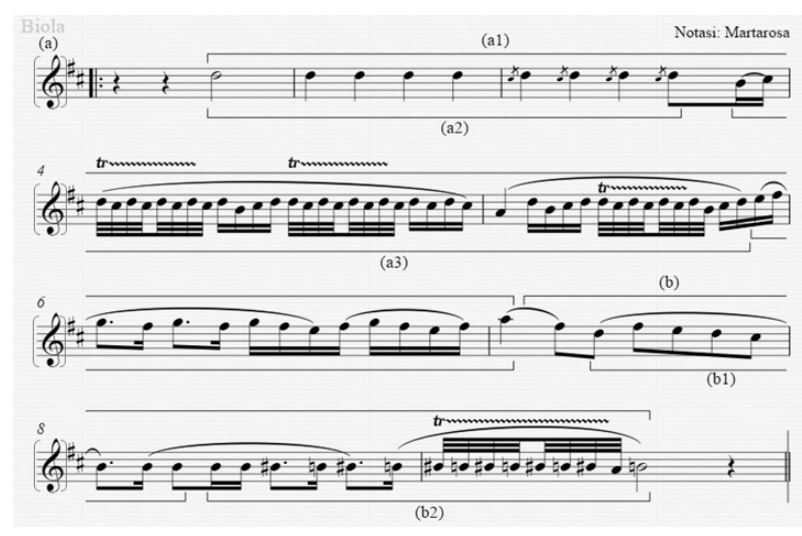

Notasi 1 (Sumber: Martarosa 2015) satu sampai dengan birama sembilan sengaja diberi tanda kurung dan tanda birama. Semestinya tidak demikian karena dimainkan secara bebas (free meter) dalam bentuk solo biola. Namun tujuannya adalah untuk memudahkan dalam melakukan analisis musik. Diamati dari bentuk melodi pada melodi introduksi dengan sistem nada yang digunakan diprediksi terjadinya gejala apropriasi musikal dari sistem nada Barat dan Arab. Hal ini ditandai pada pemakaian sistem nada diatonis dalam bentuk tangga nada $\mathrm{D}$ mayor dengan ciri menaikan nada ke enam setengah (la menjadi le).

(a1) Birama satu pada ketukan ke tiga sampai dengan birama tujuh ketukan pertama merupakan sebuah bentuk frase antecedent pada melodi bagian introduksi. Bentuk frase antecedent ini secara tidak langsung merupakan bentuk apropriasi musikal dari sistem nada Barat, kemudian dipadukan dengan ornamen musik tradisi Rabab Pasisie sebagai budaya masyarakat Pesisir Minangkabau dalam bentuk garitiak.

(a2) Birama satu dimulai pada ketukan ke tiga sampai dengan birama ke tiga pada ketukan ke empat yang beraksen merupakan sebuah bentuk figur yang terkandung dalam rangkaian melodi frase antecedent. Figur dapat diartikan sebagai kelompok kecil dari bagian motif tertentu, terjadi pada jalur melodi atau pada bagian musik iringan (Paul Fontaine, 1967: 1). Proses apropriasi musikal yang terkandung dalam bentuk figur tersebut, proses pembentukannya sama dengan bentuk (a1), namun perwujudan musikalnya dipadukan dengan bentuk ornamen nada hias dalam bentuk garitiak.

(a3) Birama tiga dimulai pada ketukan ke empat tidak beraksen sampai dengan birama lima ketukan ke empat beraksen merupakan bentuk figur pertama yang dikembangkan dalam bentuk variasi, sehingga menjadi bentuk figur ke dua dalam melodi bagian introduksi. Proses apropriasi musikal yang terkandung dalam bentuk figur ke dua ini, proses pembentukannya adalah 
sama dengan figur yang terdapat pada (a1), namun bentuk-bentuk variasi yang dikembangkan juga diapropriasi dari teknik pengembangan musik Barat. Bentuk musikal yang terkandung pada bentuk figur ke dua juga menonjolkan bentuk ornamen yang lazim ditemui pada musik tradisi Rabab Pasisie sebagai budaya masyarakat Pesisir Minangkabau dalam bentuk triller terbalik, dalam artian menyerupai triller musik Barat tetapi dengan arah nada terdekat ke bawah dalam bentuk garitiak. Triller adalah istilah untuk sebuah hiasan musik terdiri dari pergantian cepat antara nada pokok dan nada tetangga atas (sesuai dengan kedudukan dalam tangga nada yang bersangkutan) (Prier, 2011: 220). Dalam hal ini pengertian triller pada paraktek musikal musik gamat tidak murni sama tetapi meyerupai. secara terbalik mengarah ke wilayah nada bawah bukan ke wilayah nada atas.

(b) Birama tujuh dimulai pada ketukan ke dua sampai dengan birama sembilan pada ketukan ke tiga merupakan sebuah bentuk frase consequent. Proses apropriasi musikal yang terjadi pada frase consequent juga sama dengan frase antecedent, kemudian di padukan dengan bentuk ornamen-ornamen musik tradisi rabab pasisie masyarakat Pesisir Minangkabau dalam bentuk garitiak.

(b1) Birama tujuh dimulai pada ketukan ke dua tidak beraksen sampai dengan birama delapan pada ketukan kedua beraksen merupakan bentuk figur pada frase consequent, dalam bentuk apropriasi musikal dari sistem nada Barat.

(b2) Birama delapan dimulai pada ketukan ke dua tidak beraksen sampai dengan birama sembilan pada ketukan ke tiga merupakan bentuk figur kedua dalam bentuk apropriasi musikal dari sistem nada Barat dan Arab. Pengaruh sistem nada Arab seperti terlihat pada notasi di atas ditunjukan pada nada ke enam dari tangga nada yang digunakan naik setengah (nada la menjadi le). Sistem nada seperti ini lazim ditemukan pada musik tradisi Rabab Pasisie sebagai budaya masyarakat Pesisir Minangkabau dalam bentuk garitiak. Dalam artian bentuk ornamentasi yang dimaksud adalah menyerupai triller dengan menggunakan nada-nada terdekat secara terbalik.

\section{Bentuk dan Struktur Melodi dan Harmoni Lagu Pokok Bagian B}

Bentuk dan struktur melodi lagu pokok bagian B untuk vokal berjudul lagu gamat Ratok Dagang terdiri dari satu frase antecedent dan satu frase consequent dalam tanda sukat 4/4 dengan bentuk irama langgam. Struktur melodi vokal dimulai dari nada $\mathrm{d}$ dan di akhiri dengan nada e yaitu nada ke dua dari tonika dalam tangganada $\mathrm{d}$ mayor. Bentuk apropriasi musikal yang terjadi pada melodi lagu pokok bagian B, konsep pembentukannya dapat diamati dan ditandai dengan adanya penggunaan sistem tangga nada diatonis Barat dan Arab. Pengaruh sistem nada Arab sama seperti pembentukan melodi sebelumnya, seperti pada nada ke enam dari tangga nada yang digunakan naik setengah (nada la menjadi le). Khusus untuk musik iringan diapropriasi dari bentuk-bentuk musikal musik Melayu, dipadukan dengan bentuk-bentuk ornamentasi musik vokal tradisi Rabab Pasisie sebagai budaya masyarakat Pesisir Minangkabau dalam bentuk gayo melalui teknik vibrato. Secara elementer analisis bentuk dan struktur melodi lagu pokok bagian B untuk vokal ini dapat terlihat menurut urutan tanda sebagai berikut (Notasi 2).

(a) Birama duapuluh lima dimulai pada pada ketukan ke tiga tidak beraksen sampai dengan birama tigapuluh enam pada ketukan ke tiga merupakan bentuk bagian frase antecedent yang terdiri dari sebelas birama. Bentuk apropriasi musikal yang terjadi khusus pada frase antecedent disamping dipadukan dengan sistem nada Barat dan bentuk-bentuk musikal musik tradisi Pesisir Minangkabau juga di padukan dengan bentuk-bentuk melodi lagu-lagu Melayu secara umum ditandai dengan adanya penggunaan counter 
melodi di sebelum atau sesudah kalimat lagu secara responsorial. Menyerupai seperti lagu-lagu yang ada pada dondang sayang, ghazal dan ronggeng. Ditandai pula dengan ciri pergerakan nada dengan cara melompat bukan melangkah atau mengalir seperti musik tradisi Pesisir Minangkabau umumnya. Harmoni dalam pergerakan

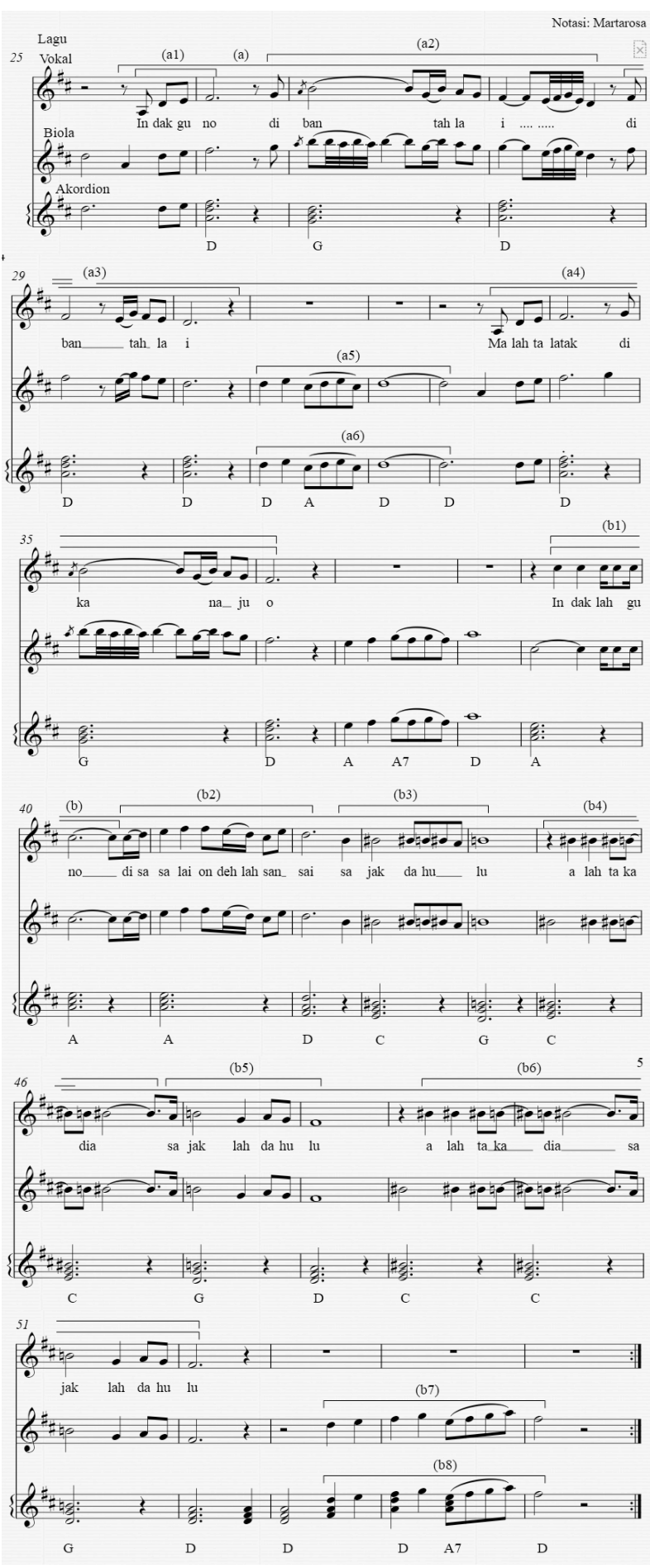

Notasi 1 (Sumber: Martarosa 2015) akord pada melodi pada bagian antecedent lagu pokok bagian $\mathrm{B}$ meliputi:

$/ \mathrm{D}$. . . . . . . . . . . . . / . . /D .../D . A ./D . . . D . . . D . . /G . . . /D . . .l. Secara musikal elemen-lemen yang terkandung dalam frase antecedent ini dijelaskan sebagai berikut:

(a1) Birama duapuluh lima dimulai pada ketukan ke tiga tidak beraksen sampai dengan birama duapuluh enam ketukan ke tiga merupakan bentuk figur pertama dari bentuk bagian frase antecedent yang disajikan dalam bentuk teknik gayo dengan menggunakan teknik vibrato. Pembentukan figur ini merupakan apropriasi musikal dari sistem nada Barat dalam bentuk gayo untuk vokal melalui teknik vibrato dan beberapa pergerakan melodi dari musik Melayu.

(a2) Birama duapuluh enam dimulai pada ketukan ke empat tidak beraksen sampai dengan birama duapuluh delapan pada ketukan ke tiga merupakan bentuk figur ke dua dari bentuk bagian frase antecedent dalam bentuk gayo dengan menggunakan teknik vibrato. Proses pembentukannya sama dengan bentuk figur ke dua juga merupakan apropriasi musikal dari sistem nada Barat dalam bentuk gayo untuk vokal melalui teknik vibrato dan beberapa pergerakan melodi seperti musik Melayu.

(a3) Birama duapuluh delapan dimulai pada ketukan ke empat tidak beraksen sampai dengan birama tigapuluh pada ketukan ke tiga merupakan bentuk diminusi dari bentuk figur sebelumnya atau bentuk figur ke dua. Proses pembentukan figur ini merupakan apropriasi musikal dari sistem nada Barat dalam bentuk gayo untuk vokal melalui teknik vibrato dan beberapa pergerakan melodi menyerupai seperti counter melodi musik Melayu.

(a4) Birama tigapuluh tiga dimulai pada ketukan ke tiga tidak beraksen sampai dengan birama tigapuluh enam ketukan ke tiga merupakan bentuk imitasi melodi dari bentuk melodi frase tanya sebelumnya. Prose pembentukannya sama dengan 
bentuk (a1) bahwa, Bentuk apropriasi musikal yang terjadi khusus pada frase antecedent disamping dipadukan dengan sistem nada Barat dan bentuk-bentuk musikal musik tradisi Pesisir Minangkabau juga di padukan dengan bentuk-bentuk melodi lagu-lagu Melayu secara umum. Sama-sama memiliki counter melodi secara responsorial, seperti lagu-lagu yang ada pada dondang sayang, ghazal dan ronggeng serta ditandai pula dengan ciri pergerakan nada dengan cara melompat bukan melangkah atau mengalir seperti musik tradisi Pesisir Minangkabau umumnya.

(b) Birama tigapuluh sembilan dimulai pada ketukan ke dua sampai dengan birama limapuluh dua pada ketukan ke empat merupakan sebuah bentuk frase consequent sebagai bagian kalimat musik pada melodi lagu pokok bagian ke dua. Bentuk apropriasi musikal yang terjadi pada melodi lagu pokok bagian frase consequent ini, konsep pembentukannya dapat diamati dan ditandai dengan adanya penggunaan sistem tangga nada diatonis Barat dan Arab. Pengaruh sistem nada Arab sama seperti pembentukan melodi sebelumnya seperti pada nada ke enam dari tangga nada yang digunakan naik setengah (nada la menjadi le), dipadukan dengan ornamentasi musik tradisi Pesisir Minangkabau dalam bentuk gayo melalui teknik vibrato. Harmoni dalam pergerakan akord pada melodi pada bagian consequent pada bagia lagu pokok B meliputi:

/A .../A . . /A . ./ D . ./C . ./ G .../ C ../ C ../ G../D ../ C ../C ../G .../D . . /D . . ./D . A7 ./ D . . ./. Secara musikal elemen-lemen yang terkandung dalam frase consequent ini dijelaskan sebagai berikut:

(b1) Birama tigapuluh sembilan dimulai pada ketukan ke dua sampai dengan birama empatpuluh pada ketukan ke empat berkasen merupakan bentuk figur pertama dari bentuk melodi lagu pokok bagian B bagian frase consequent. Proses pembentukannya sama dengan bentuk figur sebelumnya yang merupakan apropriasi musikal dari sistem nada Barat dalam bentuk gayo untuk vokal dengan menggunakan teknik vibrato.

(b2) Birama empatpuluh dimulai pada ketukan ke empat tidak beraksen sampai dengan birama empatpuluh dua pada ketukan ke tiga ini merupakan bentuk figur kedua dari bentuk melodi lagu pokok bagian B pada bagian frase consequent. Pembentukan figur ini merupakan apropriasi musikal dari sistem nada Barat dalam bentuk gayo untuk vokal dengan menggunakan teknik vibrato dan beberapa pergerakan melodi dari musik Melayu.

(b3) Birama empatpuluh dua dimulai pada ketukan ke empat sampai dengan birama empatpuluh empat pada ketukan ke empat merupakan bentuk figur ke tiga dari bentuk melodi lagu pokok bagian B bagian frase consequent. Bentuk apropriasi musikal yang terjadi pada melodi bagian frase consequent ini sama seperti sebelumnya bahwa konsep pembentukannya dapat diamati dan ditandai dengan adanya penggunaan sistem tangga nada diatonis Barat dan Arab. Pengaruh sistem nada Arab juga sama seperti sebelumnya yaitu dengan menaikan nada ke enam setengah dari tangga nada yang digunakan (nada la menjadi le). Kemudian dipadukan dengan ornamentasi musik tradisi Pesisir Minangkabau dalam bentuk gayo dengan menggunakan teknik vibrato

(b4) Birama empatpuluh lima dimulai pada ketukan ke dua sampai dengan birama empatpuluh enam ketukan ke empat beraksen merupakan bentuk variasi dari bentuk figur ke tiga sebagai bentuk melodi lagu pokok bagian B pada bagian frase consequent. Proses apropriasi musikal yang terjadi pada bentuk fihur ke tiga ini sama seperti bentuk figur sebelumnya (figur a3).

(b5) Birama empatpuluh enam di mulai pada ketukan ke empat tidak beraksen sampai dengan birama empatpuluh delapan pada ketukan ke empat merupakan bentuk figur 
ke empat dari bentuk melodi lagu pokok bagian B pada bagian frase consequent. Proses pembentukannya sama dengan bentuk figur ke empat ini juga merupakan apropriasi musikal dari sistem nada Barat dalam bentuk gayo untuk vokal dengan mengunakan teknik vibrato.

(b6) Birama empatpuluh sembilan di mulai pada ketukan ke dua sampai dengan birama limapuluh tiga pada ketukan ke empat merupakan penggabungan bentuk figur ke empat dan ke lima yang diimitasikan dari bentuk melodi frase consequent sebelumnya sebagai melodi lagu pokok bagian B. Bentuk apropriasi musikal yang terjadi pada melodi bagian frase consequent ini sama seperti sebelumnya bahwa konsep pembentukannya dapat diamati dan ditandai dengan adanya penggunaan sistem tangga nada diatonis Barat dan Arab dipadukan dengan ornamentasi musik tradisi Pesisir Minangkabau dalam bentuk gayo menggunakan teknik vibrato.

\section{Penutup}

Musik sebagai bahasa universal memiliki nilainilai estetika lokal dan universal yang dapat diterima oleh seluruh kalangan masyarakat di dunia. Tumbuh dan berkembangnya musik Nusantara tidak dapat dipisahkan dengan perjalanan sejarah di Indonesia. Musik gamat merupakan salah satu bentuk genre seni pertunjukan musik Melayu yang tumbuh dan berkembang sebagai seni budaya masyarakat di Pesisir Minangkabau Sumatera Barat.

Proses apropriasi musik gamat dalam bentuk multi kultural secara komplek dalam perwujudan budaya masyarakat Pesisir Minangkabau Sumatera Barat, merupakan salah satu pewaris budaya dari penjajahan kolonial. Proses interaksi yang terjadi dalam bentuk-bentuk unsur musikal sebagai kepemilikan atau apropriasi terhadap musik ini oleh orang-orang Pesisir Minangkabau diduga terjadi melalui penawaran-penawaran pada sisi musikal antar budaya timbal balik.

Estetika musik gamat sebagai budaya masyarakat Minangkabau di Pesisir Sumatera Barat dihadirkan/dipertahankan dalam masing-masing varian musik gamat. Secara elementer unsur-unsur musikal (konsep kreativitas melodi, musik vokal dan instrumental yang digarap dalam bentuk garitiak untuk musik instrumen dan gayo untuk musik vokal) yang tumbuh dan berkembang dalam penyajian musik gamat, selain pengaruh budaya luar dan musik Melayu Srumpun, secara musikal juga dipengaruhi oleh budaya dari dalam secara timbal balik, bersumber dari estetika musik genre musik tradisi Pesisir Minangkabau itu sendiri.

Hal ini terlihat pada salah satu lagu gamat berjudul Ratok Dagang. Bentuk dan struktur melodi introduksi menggunakan sistem tangga nada datonis yang kemudian dipadukan dengan ornamentasi bentuk garitiak. Bentuk garitiak menyerupai triller dengan menggunakan nadanada terdekat secara terbalik.

Bentuk dan struktur melodi dan harmoni lagu pokok bagian B menggunakan sistem tangga nada datonis, terdiri dari satu frase antecedent dan satu frase consequent dalam tanda sukat 4/4 dengan bentuk irama langgam yang kemudian dipadukan dengan ornamentasi bentuk gayo melalui teknik vibrato.

Dari berbagai insteraksi yang terjadi maka kontinuitas, perubahan, serta tumbuh dan berkembangnya musik gamat sebagai budaya masyarakat Minangkabau di Pesisir Sumatera Barat, dipengaruhi dan diapropriasi dari berbagai unsur-unsur musikal, baik secara eksteren maupun interen dari Portugis, Belanda, Melayu (Islam), dan Minangkabau.

\section{Kepustakaan}

Ammer, Christine. (2004). The Facts On File Dictionary of Music. New York: Mc Milan.

Bramantyo, Triyono. (2004). Disseminasi Musik Barat di Timur. Yogyakarta: Yayasan Untuk Indonesia.

Prier, Karl Edmund. (2011). Kamus Musik. Yogyakarta: Pusat Musik Liturgi.

Fontaine, Paul. (1967). Basic Formal Structures In Music. New York: Appleton-Century-Crofts. Ganap,Victor, (2011). Kronjtong Toego. Yogyakarta: BP ISI. 
Harper-Scott, J.P.E; Jim Samson. (2009). An Introduction to Music Studies. New York: Cambridge University Press.

Hendrizal. (2013). Studi Analisis: Nilai-Nilai Estetika Lokal Dalam Musik Gamat, Jurnal Ekspresi Seni, 15 (1).

Irawan, Endah, dkk., (2014). Karakter Musikal Lagu Gede Kepesindenan Karawitan Sunda. RESITAL : JURNAL SENI PERTUNJUKAN (15) 1.

Mistortoify, Zulkarnain, dkk., (2014). Pola Kellegban dan Teknik Vokal Kejbungan Representasi Ekspresi Budaya Madura dan Pengalaman Estetiknya. RESITAL :JURNAL SENI PERTUNJUKAN, 15 (1).

Murniati. (2015). Dekonstruksi Estetika dan Makna Musik Gamat di Sawahlunto, Sumatra Barat. RESITAL : JURNAL SENI PERTUNJUKAN, 16 (1): 25-35.

Romengan, Perry. (2010). Hubungan Fungsional; Struktural Musikal-Aspek Ekstra Musikal Muisk Vokal Etnik Minahasa. Yogyakarta: Program Pascasarjana ISI Yogyakarta.

Schneider, Arnd. (2006). Appropriation As Practice: Art and Identity in Argentina. New York: Palgrave Macmillan.

Simatupang, Lono. (2013). Pergelaran Sebuah Mozaik Penelitian Seni Budaya, Yogyakarta: Jalasutra.
Simatupang, Lono. (2010). "Seni Dan Estetika: Perspektif Antropologi”, Makalah disampaikan dalam Seminar "Estetika Nusantara”, Program Pascasarjana, Institut Seni Indonesia, Surakarta.

Sriyanto. (2012). Dimensi Estetika Pertunjukan Saluang Dendang Di Minangkabau Dalam Bagurau. Jurnal Ekspresi Seni. 14 (2).

Sumarsam. (2016). "Soal-Soal Masa Lampau dan Kini Seputar Hibriditas Musik Jawa Eropa: Gendhing Mares dan Genre-Genre Hibrid Lain”. Dalam Bart Barendregt dan Els Bogaerts. Merenungkan Gema Perjumpaan Musikal Indonesia-Belanda (Recollecting Resonances: Indonesia-Dutch Musical Encounters). Jakarta: Yayasan Pustaka Obor Indonesia.

Svasek, Maruska. (2007). Anthropology, Art And Cultural Production. London: Ann Arbor, MI.

\section{Webtografi}

http://en.wikipedia.org/wiki/Appropriation (music), diakses pada tanggal 15 Desember 2014

\section{Informan}

Tawanto Karim. Pemain dan pimpinan Kelompok Musik Gamat. Tinggal di Mata Air, Padang. 